\title{
Perception of Social Responsibility Strategy in Higher Education: Empirical Study in Poland
}

\author{
Małgorzata Kieżel $^{1, *(\mathbb{D})}$, Paweł Piotrowski ${ }^{2, *(\mathbb{D})}$ and Joanna Wiechoczek ${ }^{1}$ (D) \\ 1 Department of Marketing Management and Tourism, University of Economics in Katowice, Ul. 1 Maja 50, \\ 40-287 Katowice, Poland; joanna.wiechoczek@ue.katowice.pl \\ 2 Department of Management Theory, University of Economics in Katowice, Ul. 1 Maja 50, \\ 40-287 Katowice, Poland \\ * Correspondence: malgorzata.kiezel@ue.katowice.pl (M.K.); pawel.piotrowski@ue.katowice.pl (P.P.)
}

Citation: Kieżel, M.; Piotrowski, P.; Wiechoczek, J. Perception of Social Responsibility Strategy in Higher Education: Empirical Study in Poland. Sustainability 2021, 13, 9417. https://doi.org/10.3390/su13169417

Academic Editors: Inês Ribeiro,

Tiago Domingos and Silvia Di Salvatore

Received: 29 June 2021

Accepted: 18 August 2021

Published: 22 August 2021

Publisher's Note: MDPI stays neutral with regard to jurisdictional claims in published maps and institutional affiliations.

Copyright: (c) 2021 by the authors. Licensee MDPI, Basel, Switzerland. This article is an open access article distributed under the terms and conditions of the Creative Commons Attribution (CC BY) license (https:// creativecommons.org/licenses/by/ $4.0 /)$.

\begin{abstract}
Today, the role of universities in the education of future managers who promote the principles of social responsibility (SR) and CSR in business practice is pivotal. Properly educated management staff of organizations can disseminate knowledge on this subject and apply its principles in practice. The research scope of the paper is to identify the knowledge and perception of the University Social Responsibility Declaration (Polish national programme in this field, hereinafter called USRD) among the students of the University of Economics in Katowice. The research assumes that most of the students do not have any knowledge about such programs as the USRD, and that despite this, they see the need for implementation of the specific principles of the USRD into university's activities. Significance of specific principles is associated with students' sociodemographic and psychographic characteristics. The strongest relation between the perception of the importance of the objectives of USRD and students' characteristics is observed in the declared extent to which respondents implement the principles of social responsibility in their everyday life, as well as in their age and year of study. The more the students use those principles, the higher they personally rate specific principles of the USRD.
\end{abstract}

Keywords: University Social Responsibility; sustainability in higher education; knowledge; information's sources; students' perception

\section{Introduction}

Many economic, political, and social changes influence universities' missions, structures, organization strategies and profiles, modes of operation, and provision of knowledge to society and stakeholders. University Social Responsibility (USR) is a philosophy that must be embraced by any higher education institution as an ethical approach to expand and become involved with the regional and global community. This approach supports sustainable economic, ecological, social, environmental, and technical development of society. It can be implemented by the responsible management of learning, labour, and environmental influence from the academy; by provision of teaching, research and service; and also by interactive communication with community, business, and so forth [1]. Knowledge of students' attitudes towards issues of responsibility is therefore necessary. Students, as internal stakeholders of the university, represent it on the outside. Knowledge of the USR concept among students and their attitudes towards this concept are important for the current and future relations of the university with the environment. Presently, educating future managers who are aware of the need for and importance of the USR concept is of great importance for business and the wider environment. For this to be possible, universities must ensure their competitiveness in terms of up-to-date programs and shaping socially responsible attitudes.

The initiative of the Declaration of Universities for Social Responsibility was inaugurated by Polish universities in 2017. At that time, 23 universities joined the Declaration, 
and now there are 58 of them [2]. In September 2019, the University of Economics in Katowice, which is the most relevant economics university in the Silesia region, joined this initiative. The University of Economics in Katowice was the only Polish university that filed the social responsibility and sustainable development report in the Global Reporting Initiative. GRI-Global Reporting Initiative is the independent, international entity that helps companies and various organizations (including universities) take responsibility for their impacts on people and the planet by providing them with homogeneous standards by which to communicate those impacts (www.globalreporting.org (accessed on 10 May 2021)) through a database (it contains social responsibility reports of a total of 133 universities from 32 countries). Accordingly, the purpose of this paper is to identify the knowledge about this new initiative, i.e., the University Social Responsibility Declaration, among students at the University of Economics in Katowice, and to recognise its perception by them.

The research assumes that the majority of the students at the University of Economics in Katowice do not have any knowledge about such programs yet. Moreover, it is assumed that there is a correlation between the perception of the importance of SR objectives and specific students' sociodemographic and psychographic characteristics.

A critical analysis of the literature on the subjects of sustainable development, Corporate Social Responsibility, and University Social Responsibility (based on books, journals, and Internet sources) as well as documentary methods are used in the research. The results of quantitative research based on survey research methodology (with the use of the CAWI method) are presented. Previous research in this field focuses on University Social Responsibility from the perspective of students and other university stakeholders. This research focuses on various problems, mostly fragmentary and most often related to one university [3-6].

The paper consists of four parts. The first is a brief review of the literature on sustainable development and Corporate Social Responsibility (CSR). Then, the authors identify the essence of University Social Responsibility and its specificity. Next, the methodology of the empirical survey research and the characteristics of respondents are presented. The authors also describe the research results-the perception of the USRD by students. Finally, the limitations and the future trends of the research are discussed.

\subsection{The Concept of Sustainable Development and Its Relationship with Corporate Social Responsibility - Review of the Scientific Literature}

The notion of sustainable development was defined in 1987, in the "Our Common Future" report of the UN World Commission on Environment and Development, as a process that "meets the needs of the present without compromising the ability of future generations to meet their own needs" [7]. While planning effective strategy for achievement of sustainable development, the following three primary areas should be considered [8]:

- nature protection and effective management of resources (e.g., reduction of environment pollution, protection of endangered species of plants and animals, and promotion of renewable energy sources);

- economic growth and fair division of resulting profits (e.g., easier access to markets for developing countries, funding development, and changing irrational patterns of consumption and production);

- $\quad$ social development (e.g., combating poverty and access to education and health protection).

This concept has been evolving over time, and other aspects were added to this concept, which are presented in Table 1. 
Table 1. Major aspects of sustainable development.

\begin{tabular}{cc}
\hline Aspect & Characteristics \\
\hline Ecological & $\begin{array}{c}\text { the process of reduction of environmental degradation, constant improvement of } \\
\text { the environment's condition, and implementation of integrated environmental } \\
\text { systems, as well as development and implementation of ecological policy }\end{array}$ \\
\hline Civilisation & $\begin{array}{r}\text { the process of searching for and implementing modern technologies, searching for } \\
\text { new energy sources, and social communication, as well as implementation of new } \\
\text { forms of non-economic activity in society }\end{array}$ \\
\hline Social & $\begin{array}{r}\text { development and implementation of social policy, whereas the economic aspect } \\
\text { makes it necessary to develop and implement strategy and policy for } \\
\text { state development }\end{array}$ \\
\hline Spatial & $\begin{array}{r}\text { the development of innovative approaches to spatial planning and formation of } \\
\text { spatial policy (the political and institutional aspects create the obligation to } \\
\text { observe the principles of the discussed development in politics and management) }\end{array}$ \\
\hline Economic & $\begin{array}{c}\text { practices that support long-term economic growth without negatively impacting } \\
\text { social, environmental, and cultural aspects of the community }\end{array}$ \\
\hline Source: Own study based on [9] (pp. 21-40); [10](p. 1)
\end{tabular}

Source: Own study based on [9] (pp. 21-40); [10] (p. 1).

The concept of sustainable development that emphasises the need to take into consideration social and environmental aspects, rather than solely the economic dimension of business activity, is perceived as a very important factor determining the growth of interest in the creation of socially responsible business model by an organization [11]. For this reason, the idea of sustainable development includes the concept of Corporate Social Responsibility (CSR). According to Davis and Blomstrom [12], CSR should be approached as the obligation of a corporation's management to make such decisions and actions that will contribute both to taking care of their own interests and the protection and growth of social well-being. Social responsibility is "the practice of going beyond legal regulations (obligations) for effective balancing of obligations towards investors, customers, other enterprises and other communities" [13]. CSR should also have a strategic and long-term impact, based on the principles of social dialogue $[14,15]$. CSR focuses on a specific organization and constitutes both a philosophy and a set of tools allowing for the achievement of the condition of sustainable business that, apart from benefits for environment and society, provides long-lasting growth of enterprises [16]. Major areas of social responsibility include the fulfilment of ancillary obligations. This means care for the interests of organization stakeholders, e.g., observance of human rights, through suitable protection of customers and development of products with a view of their needs, contribution to creation of well-being, creation of workplaces, care about workers and their families, care about the natural environment, and observance of legal regulations and principles of ethics among others $[17,18]$.

In turn, according to Ebner and Baumgartner [19], CSR focuses especially "on the corporate engagement, realizing its responsibilities as a member of society and meeting the expectations of all stakeholders". Therefore, they recommend treating CSR as a social aspect of the concept of sustainable development.

The concept of CSR involves several key assumptions [20]. Business and society are elements of a larger whole, wherein the idea of mutual solidarity between people is of primary importance, and contribution to the growth of prosperity and improvement of citizens' quality of life is the strategic business target. To maintain their role in the long term, enterprises are encouraged by the dynamic nature of the social system to follow behaviours that are mainly preventive but also risk-anticipating in the social sphere. The minimum level of economic and legal corporate responsibility is determined by the demands of the community living on a specific stage of social development. Every action of an enterprise that manifests care about the consumer, staff-related matters, and natural environment protection; goes beyond the minimum level of ethical responsibility demanded by law; and corresponds to community expectations contributes to strengthening of its competitive 
position in the market. The type and scope of responsibility towards society adopted by the enterprise are reflected in its structural and organizational preparation for implementation of social goals, which are adjusted to demands and expectations of target markets.

Some researchers use the notions of Corporate Social Responsibility and sustainable development interchangeably [21-23]. D. Ebner and R. J. Baumgartner [19] compared 43 papers from 1998-2006 in terms of the relationship between CSR and sustainable development. The authors of 16 of the analysed papers concluded that the terms CSR and sustainable development can be used synonymously. It is very important that the concept of sustainable development refers not only to business entities, but also concerns the behaviour of local government units, all state institutions, and the whole of society. For both concepts, the guiding principles are care for stakeholders and the assessment of the impact that products and enterprises operations have, with respect to their own good [24]. Such an interpretation of Corporate Social Responsibility emphasises the need for companies to refrain from actions that are socially harmful, even if they are profitable. On the other hand, undertaking actions that are oriented towards prevention and reduction of various negative social phenomena gains importance. On this basis, it can be stated that the notion of sustainable development definitely has a broader scope than social responsibility, which constitutes an element of sustainable management. Despite ambiguities, it is possible to identify three common elements. They are justice (taking into consideration the rights of the poor and future generations), long-term point of view in application of the caution principle, and a systemic way of perceiving sustainable development that enables understanding of mutual relationships between the environment, economy, and society [25] (p. 59). Activities in the sphere of social responsibility are accompanied by principles that are not imposed by law but shaped under strong social pressure. They concern, among other things, social dialogue and workers' representation. These principles should also be helpful in the voluntary development of various forms of social responsibility that better meet the needs of contemporary society and economy, as well as in ensuring sustainable development.

The European Union (EU) defines CSR as "the voluntary integration by companies, of social and environmental concerns in their business operations and in their interaction with their stakeholders" [26] (p. 20). A few years later, this definition has been revised, pointing to "the responsibility of enterprises for their impacts on society" and emphasising the need for collaboration with stakeholders to "integrate social, environmental and ethical concerns, respect for the human rights and consumer concerns into their business operations and core strategy" [27]. The works in the field of Corporate Social Responsibility can be the basis for developing the concept of University Social Responsibility [28-31].

\subsection{University Social Responsibility Concept}

Educational institutions supply knowledge transfer services. The customers are individuals, private and public organizations, and the entire society. According to UNESCO, education is a base for economic, social, and environmental development. It is the way to create a learning society and achieve sustainable conditions. Universities are the centres of information and skills. They play a principal role in the scientific, social, cultural, and economic growth of society. These institutions maintain and enhance knowledge and perform academic research and innovative activities. They also play a pivotal role in the formation of mutual understanding, civil society, and cultural diversity. The significance of the concept of Corporate Social Responsibility for universities is obvious. This comes from the specific institutional character, social importance, and mission of universities [32].

The university which has integrated a socially responsible vision in its development strategy is concerned with promoting and implementing a set of general principles and specific values by using four processes: education, research, management, and extension through delivering educational services. This means that the responsibility to contribute to social betterment should be shared by universities through the integration of social responsibility policies into institutional management, teaching, research, services, and public activities [33] (p. 13). The transfer of knowledge compliant with standards of ethics, 
fair governance, respect for the environment, social involvement, and promotion of values is also very important [34] (pp. 231-238). However, there is no widely accepted definition of the USR concept in the literature. Reiser [35] defines the University Social Responsibility (USR) concept as "a policy of ethical quality of the performance of the university community (students, faculty and administrative employees) via the responsible management of the educational, cognitive, labour and environmental impacts produced by the university, in an interactive dialogue with society to promote a sustainable human development". Domínguez Pachon [36] understands the USR concept in a similar way, emphasizing four key processes by which universities can disseminate and implement a set of general principles and specific values: management, teaching, research, and extension. In turn, a general model of USR in a universal context was proposed by Vasilescu et al. [37] (pp. 4177-4182). According to it, USR is "an ethical approach whereby university students and academic staff are encouraged to embrace the notions of civic commitment and voluntary contribution to social services". Esfijani, Hussain, and Chang [38] (p. 280) proposed the broadest definition of the USR concept. They understand it as "a concept whereby a university integrates all of its functions and activities with the society needs through active engagement with its communities in an ethical and transparent manner which aimed to meet all stakeholders' expectations". It is worth noting that, despite some differences in defining the USR concept, each definition emphasizes the partnership of universities with their stakeholders (these are described further). The stakeholder approach is referred to, explicitly or implicitly, in many other definitions of the USR, e.g., $[1,5,19,39]$. On this basis, it can be concluded that stakeholders are a key element of the USR concept. Students are one of the key stakeholder groups for universities.

The USR represents a superstructure of university statutory responsibility and aims to support the development of the university environment. According to this concept, the university administration, managers, and employees act in such a way as to enable the implementation of the university's economic and social mission and facilitate the implementation of the plans and goals of all stakeholders. According to Tetřevová and Sabolova [40] the key components of the USR practices include five dimensions: (1) Economic (e.g., corporate governance principles; relationships with stakeholders-students, course applicants, staff, providers, firms, communities, other educational organizationspartners and competitors alike; openness; quality and safeness of the provided articles and services); (2) Ethical (e.g., corruption disclaimers; intellectual property protection, especially copyright protection); (3) Sub-Social (e.g., employment policy, staff training and qualifications growth, employees' health and security, work-life balance, equal opportunities in the workplace); (4) Environmental (e.g., environmental organizational structure, natural resources protection, investments into environmentally friendly technologies, environmentally friendly products and services); (5) Philanthropic (e.g., university volunteering and charity).

Other dimensions of University Social Responsibility practices are proposed by Dima, Vasilache, Ghinea, and Agoston [41]. According to them, a model of social responsibility is based on six groups of activities. They are alumni-oriented projects, inter-university cooperation, university cooperation with high schools and other institutions, communityoriented university-business environment cooperation, community-oriented international cooperation, and socio-cultural and ecological projects. More generally, the dimensions of USR are defined by Brdulak [42]. She stresses four basic areas of the university's activity, i.e., external relations, internal relations, conducting research, and education.

USR covers many issues that should be integrated with the planning and activity of a university. This is a significant feature of universities' interactions with internal and external stakeholders [43] (p. 166). The stakeholder is "an individual or group that has some kind of stake in what business does and may also affect the organization in some fashion" [44] (pp. 137-148). A university's stakeholders include its undergraduates and alumni (students are viewed as "either the products or the customers of faculties"), its applicants, its academic and non-academic staff, businesses (including prospective 
employers and companies which cooperate with the university), the media, sponsors, other educational institutions, governments on different levels, and the public. In the case of private universities, they also include the owners and other investors [45] (pp. 69-76), [46] (pp. 430-431).

It is important to strengthen civic engagement through the University Social Responsibility concept—for example, through volunteering, encouraging students and academic staff to provide social services for the local community, and promoting green attitudes and environmental commitment $[1,5]$. The comprehensive implementation of the USR concept requires universities to change their development strategy by introducing a responsible approach into their management activities and their educational and research programs [47]. The effective implementation of the USR concept is considered to be one of the most important factors for the development of the university education system. Moreover, socially responsible practices can increasingly become a long-term value proposition for the university itself [48].

Considering the research subject of this paper, in the literature there are several empirical studies on University Social Responsibility from the perspectives of students and other university stakeholders. They focus on various problems, mostly fragmentary and mainly related to one university. They concern, in particular, the comprehension of Corporate Social Responsibility in a cross-cultural higher education context by students at universities in Spain, Poland, and Bulgaria [49]. Other issues include the perceptions of the students regarding social responsibility practices (at the University of Valencia in Spain) [50]; the perceptions and attitudes of students regarding CSR in organizations and their experiences of current and desired education on the matter (at the Uruguayan University) [51]; the students' opinions about the determinants of the implementation of the concept of social responsibility by higher education institutions (this research was conducted in several universities in southern Poland) [52]; social responsibility perceptions among students and their behaviours (how universities manage USR and what their role should be according to students) [3,4]; the students' perceptions regarding the four impacts of USR, including organizational, educational, cognitive, and social, and overall understanding of university contribution to society, environment, and economy (at the University of León in Spain) [5]; and the perspectives of internal stakeholders on social responsibility initiatives and processes at a private university (in Puerto Rico) [53].

In the research presented in the following section of this paper, the authors examined relations between specific principles of the USRD and six variables related to sociodemographic and psychographic characteristics of students. These were gender, age, year and type of study, study mode, professional activity, and declared implementation of the social responsibility principles in everyday life. Gender was chosen because results of different research show that women are more likely to use principles of social responsibility in their lives [6,54]. As a result, we could suppose higher personal ratings of the USRD principles' importance among women. The age of the respondents was taken into consideration because there are no studies that unambiguously show the relationship between age and approach to the CSR concept. Some studies show that younger generations see the need for implementation of this concept to a greater extent $[55,56]$. However, it should be emphasized that due to the subjective scope of the research, the age group is relatively homogeneous. Taking into account the year and type of studies stems from the presumption that people at higher degrees of studies probably have more knowledge about the concept of CSR and are more aware of the role that universities play in the implementation of social responsibility. As a result, the individual rating of the USRD principles should be higher. Another characteristic was study mode. This characteristic was taken into consideration because full-time students should be more aware of the need for socially responsible behaviour and, at the same time, see the significant role of universities in shaping such attitudes within society. Due to the changes taking place in society, it is currently impossible to equate full-time students with people not working (at least in Poland), and therefore students were also asked about their professional activity. Two 
presumptions could be made about this feature. On the one hand, it could be assumed that non-working people have a more idealized image of reality and will more highly rate principles of the University Social Responsibility Declaration than working people. On the other hand, people studying and working are usually at the beginning of their careers. Clashing with the market reality does not always correspond to what they imagined. Despite the spreading CSR trend, in many cases, it is not followed in practice. Hence, the need for education in this regard is noticed by working students. The last characteristic was the declared implementation of the social responsibility principles in everyday life. It could be assumed that people declaring the application of social responsibility principles on a daily basis would pay more attention to the necessity of the university and the field of education implementing the principles of the USRD.

\section{Research Methodology and Sample Characteristics}

The University Social Responsibility Declaration (USRD) is an unsolicited commitment of Polish universities to promote the concepts of sustainable development and social responsibility in education, scientific research, management, and organizational rules and procedures. The Declaration's goal is to actively create social awareness regarding the role of universities in shaping conditions for sustainable social and economic development of the state [57]. The Declaration can be accepted by all public and private universities operating in Poland.

Similar initiatives implemented by individual universities or university networks (include national and/or international entities) can be identified. Examples include the global University Social Responsibility Network [58]; regional networks such as EU-USR (University Social Responsibility in Europe) [59], Ma'an Arab University Alliance for Civic Engagement, the South African Higher Education Community Engagement Forum, and Engagement Australia [33] (p. 13); but also national networks such as the USR Program in Taiwan [60]. Although detailed goals of the above-mentioned networks are different, their main goal is to encourage member universities to implement the ideas of sustainable development and social responsibility in their educational programs, scientific research, and management and organizational solutions.

The University of Economics in Katowice, studied in this paper, signed the abovementioned Declaration on 17 September 2019. Therefore, the purpose of the paper is to identify knowledge and perception of the University Social Responsibility Declaration among students at the University of Economics in Katowice (Poland).

The following research questions were formulated:

- What knowledge exists among the students at the University of Economics in Katowice about the University Social Responsibility Declaration (USRD)?

- To what extent, according to the surveyed students' opinions, should universities signing the USRD pursue its principles?

- What is the importance of the specific principles of the USRD for the surveyed students?

What is the association between students' sociodemographic and psychographic characteristics and their perception of USRD principles? One research tool was a survey questionnaire (questionnaire subjected to validation-Chi-squared test value). The questions in the questionnaire were prepared on the basis of the 12 principles (they are presented in Table 4) contained in the University Social Responsibility Declaration (universities should apply these principles to achieve the highest management standards, manage resources more efficiently, actively develop university staff, and create their own prestige as generators of knowledge and creators of innovative ideas). These principles relate to four basic areas of USR activity at the University of Economics in Katowice, i.e., education and scientific research; social (external and internal relations); ecological; and economic. The indicated areas are consistent with the general assumptions of the USR concept.

As was said in previous sections, this concept stems from the concepts of sustainable development and CSR. The impact of the sociodemographic and psychographic variables (i.e., year, type and mode of study, and lifestyle according to the principles of sustainable 
development) on the knowledge and perception of the USRD among the students at the University of Economics in Katowice was determined with the help of correlation coefficients.

The study was conducted online using the CAWI method (the questionnaire is added in the Supplementary Materials). It was performed in November and December 2019. There were 315 students who participated in the survey. They mostly represented Generation $Z$. Non-random quota sample selection was applied. The share of the students in the sample was determined in such a way that it was proportional to their actual share in the total student population of the studied university by gender as well as year and type of study. Respondents were also categorized according to their age, study mode, professional activity, and declared implementation of the social responsibility principles in everyday life, according to other research related to this topic. The sample's characteristics are shown in Table 2.

Table 2. Characteristics of respondents.

\begin{tabular}{|c|c|c|}
\hline Criterion & Frequency & Percent \\
\hline \multicolumn{3}{|l|}{ Gender } \\
\hline Women & 192 & 61 \\
\hline Man & 123 & 39 \\
\hline Total & 315 & 100 \\
\hline \multicolumn{3}{|l|}{ Age } \\
\hline Under 20 & 57 & 18.1 \\
\hline $21-22$ & 101 & 32.1 \\
\hline $23-26$ & 105 & 33.4 \\
\hline 27 and older & 52 & 16.4 \\
\hline Total & 315 & 100 \\
\hline \multicolumn{3}{|c|}{ Year and Type of Study } \\
\hline Bachelor studies/1st degree (1st to 3rd year) & 157 & 49.9 \\
\hline Master studies / 2nd degree (MA) & 145 & 45.9 \\
\hline 3rd cycle (doctoral) studies or postgraduate studies & 13 & 4.2 \\
\hline Total & 315 & 100 \\
\hline \multicolumn{3}{|l|}{ Study Mode } \\
\hline Full-time & 201 & 63.8 \\
\hline Part-time (extramural studies) & 114 & 36.2 \\
\hline Total & 315 & 100 \\
\hline \multicolumn{3}{|c|}{ Professional Activity during Studies } \\
\hline Yes, permanent employment contract & 115 & 36.5 \\
\hline Yes, contract orders & 88 & 27.9 \\
\hline No & 112 & 35.6 \\
\hline Total & 315 & 100 \\
\hline \multicolumn{3}{|c|}{ Declared Implementation of the Social Responsibility Principles in Everyday Life } \\
\hline To a very high or high extent & 146 & 46.3 \\
\hline Neither to a high nor to a low extent & 139 & 44.1 \\
\hline To a very low or low extent & 30 & 9.6 \\
\hline Total & 315 & 100.0 \\
\hline
\end{tabular}

Source: Own research.

Prior to performing analysis, the construct reliability and suitability were assessed by calculating the Cronbach's Alpha and the Kaiser-Meyer-Olkin value. In all cases, we obtained values above the threshold of 0.7 (Table 3). 
Table 3. Results of data reliability and suitability regarding collected data.

\begin{tabular}{cccc}
\hline Specification & No. of Items & Cronbach's Alpha & $\begin{array}{c}\text { KMO Measure of } \\
\text { Sampling Adequacy }\end{array}$ \\
\hline $\begin{array}{c}\text { Perceived importance of objectives of the } \\
\text { University Social Responsibility programme }\end{array}$ & 8 & 0.902 & 0.846 \\
\hline $\begin{array}{c}\text { Personal importance rating of specific } \\
\text { principles of the University Social } \\
\text { Responsibility programme }\end{array}$ & 12 & 0.881 & 0.869 \\
\hline
\end{tabular}

Source: Own research.

\section{Results}

At first, respondents were asked about their knowledge of the University Social Responsibility Declaration (USRD). Almost $82 \%$ of the surveyed students had not heard of this declaration yet. A similar percentage of respondents $(81.6 \%)$ did not know that the University Social Responsibility Declaration had been signed by the University of Economics in Katowice. Analysing both answers, the general conclusion is that the majority of respondents do not have any knowledge about the USRD.

In the second section, respondents were asked about the extent to which universities that sign this type of a declaration should pursue the mentioned objectives. A five-point Likert scale was used, where 1 means that the objective is not important at all, while 5 means that it is very important. On this basis, weighted arithmetic means were calculated for each objective and are presented in Figure 1.

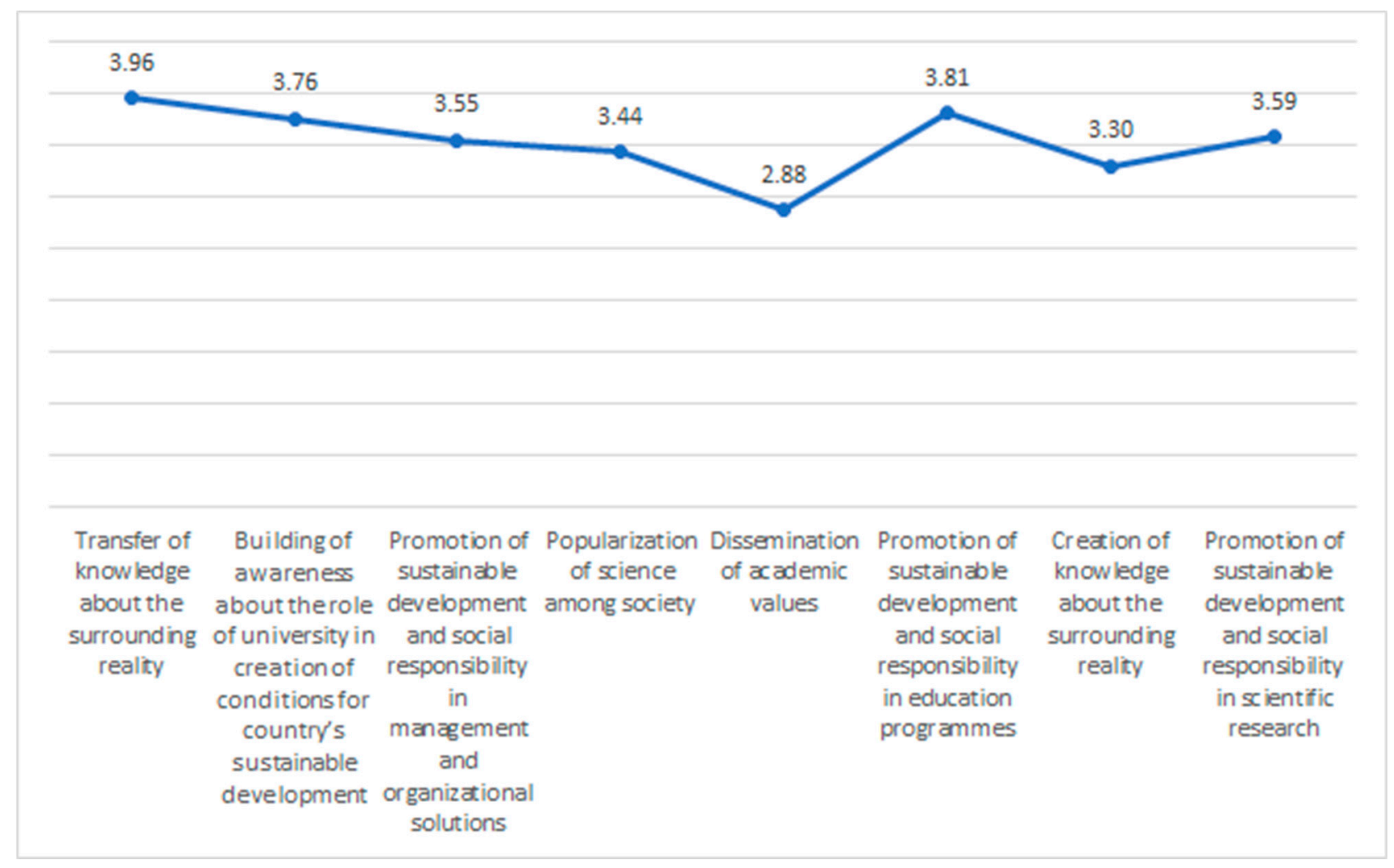

Figure 1. The extent to which universities signing the USR Declaration should pursue the mentioned objectives—according to the respondents' opinions.

The results show that the most important objectives for students were those related to the education process: transfer of knowledge about the surrounding reality (mean 3.96) and promotion of sustainable development and social responsibility in education programmes 
(mean 3.81). It is worth noting that the latter received the highest number of "to a very high extent" and "to a high extent" responses ( $74.6 \%$ of indications in total).

Goals related to the general promotion of Corporate Social Responsibility/science among various stakeholder groups form the second group of goals (according to the results of arithmetic mean averages). These range in mean from 3.76 in the case of building of awareness about the role of university in creation of conditions for a country's sustainable development to 3.44 in the case of popularization of science among society.

Least important for the respondents were the issues related to rather intrinsic aspects of a university's activity and its culture, i.e., creation of knowledge (mean 3.3) and dissemination of academic values (2.88).

In the third section, the respondents rated the importance of 12 specific principles of the University Social Responsibility Declaration for themselves personally. It is worth noticing that these 12 principles emphasize different kinds of relations between university and environment. According to proposals made by Dominguez Pachon [36], Vallaeys et al. [61], and Brdulak [42], we can distinguish at least four groups of relations, as presented in Table 4.

Table 4. Groups of relations between principles of University Social Responsibility Declaration in connection with aspects of sustainable development.

\begin{tabular}{|c|c|c|}
\hline Group of Relations & The 12 Principles of USRD & Aspects of Sustainable Development \\
\hline \multirow[t]{3}{*}{ External relations } & $\begin{array}{l}\text { Dissemination of ideas of equal opportunities, diversity, } \\
\text { tolerance, and respect for human rights }\end{array}$ & Social \\
\hline & $\begin{array}{c}\text { Activity of academic community and their stakeholders } \\
\text { in the way that minimizes its negative impact on } \\
\text { natural environment }\end{array}$ & Ecological, Economic \\
\hline & Providing transparency of university's activity & Social \\
\hline \multirow[t]{3}{*}{ Cooperation } & $\begin{array}{l}\text { Undertaking national and international cooperation in } \\
\text { terms of scientific research and implementation work }\end{array}$ & Civilisation, Economic \\
\hline & $\begin{array}{l}\text { Development of national and international } \\
\text { intercollegiate cooperation in terms of exchange of social } \\
\text { responsibility models }\end{array}$ & Social \\
\hline & $\begin{array}{l}\text { Dialogue with stakeholders about priorities of USR } \\
\text { policy and providing information about its results }\end{array}$ & Civilisation, Economic \\
\hline \multirow[t]{3}{*}{ Education } & $\begin{array}{c}\text { Creation of social and civic attitudes of elites towards } \\
\text { building work ethics }\end{array}$ & Civilisation \\
\hline & $\begin{array}{c}\text { Extension of education programmes concerning the } \\
\text { issues related to ethics and CSR, sustainable } \\
\text { development, and social innovations }\end{array}$ & Social, Civilisation, Ecological, Spatial \\
\hline & $\begin{array}{l}\text { Submitting the rules of ethics and responsibility in } \\
\text { education and research processes }\end{array}$ & Social, Ecological, Spatial \\
\hline \multirow[t]{3}{*}{ Internal relations } & $\begin{array}{c}\text { Taking care of academic values (e.g., those mentioned in } \\
\text { the "Code of Ethics of a Researcher") }\end{array}$ & Social \\
\hline & $\begin{array}{c}\text { Undertaking projects implementing the principles of } \\
\text { social responsibility in the process of } \\
\text { University management }\end{array}$ & Social \\
\hline & $\begin{array}{l}\text { Taking care of university's organizational order in } \\
\text { strategies and actions based on principles of USR }\end{array}$ & Social, Spatial \\
\hline
\end{tabular}

The first group concerns the principles associated with external relations between the university and the general environment, such as providing transparency of university's activity. The second group refers to cooperation with specific groups of stakeholders, including different universities, companies, and NGOs. The third group covers the principles 
focused on students and education processes. The last group is devoted to actions of the university of mainly internal importance.

To calculate weighted arithmetic mean, the same methods as in Figure 1 were used. Different colours were used for the principles, representing the various groups of relations presented in Table 4. It can be seen that most important for respondents were two principles associated with relations between the university and the general environment-the dissemination of ideas of equal opportunities, diversity, tolerance and respect for human rights (4.43) and activity of academic community and their stakeholders in the way that minimizes its negative impact on natural environment (4.33) (Figure 2).

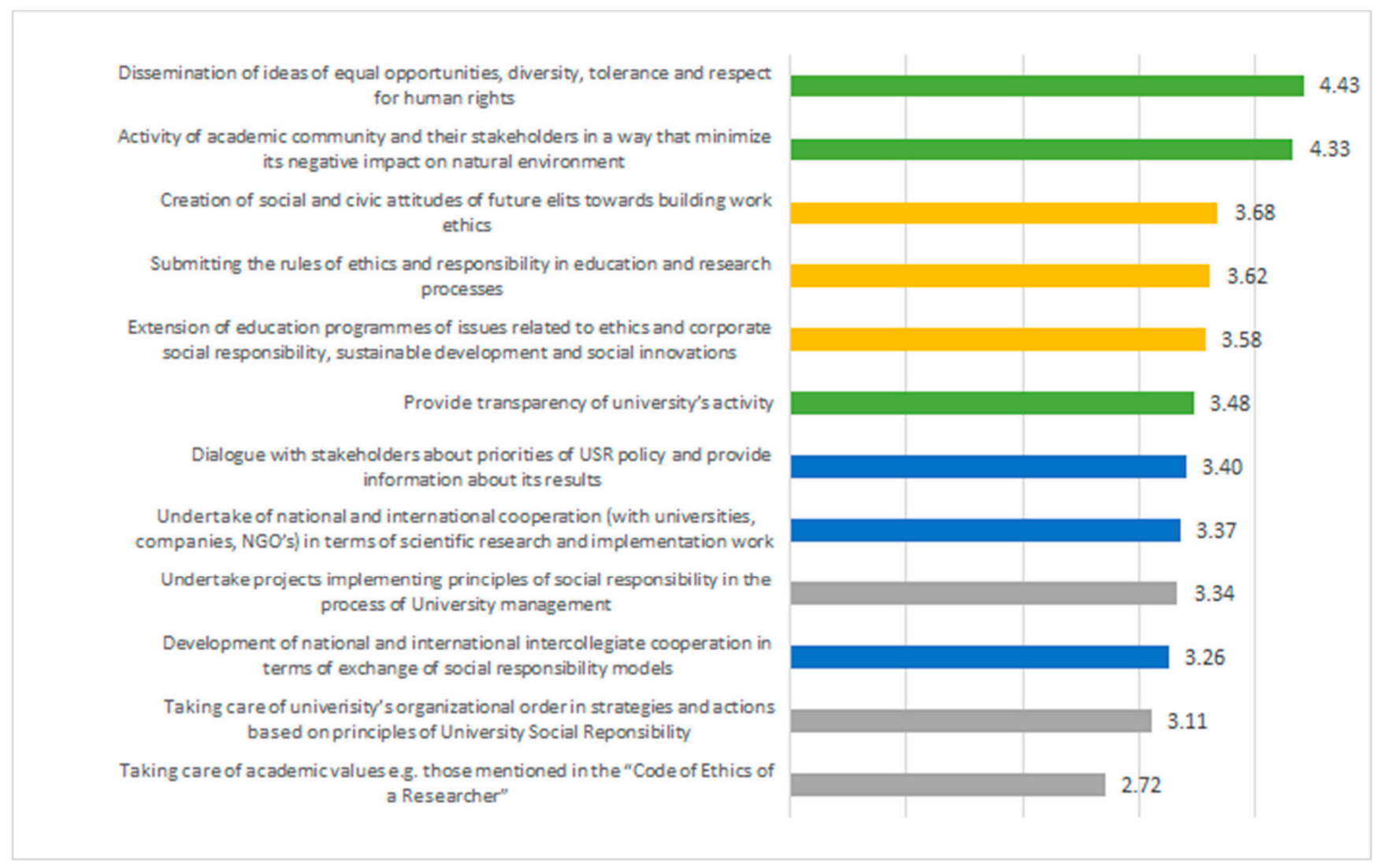

Figure 2. Respondents' rating of the importance of specific principles of the University Social Responsibility Declaration for themselves personally.

There is a significant difference between the first two principles and those that follow. The next three principles (marked in yellow colour) are associated with students and the education process. The sixth is again related to relations with the general environment. The last six principles refer to those associated with cooperation between the university and specific stakeholders (marked in blue colour) and those with internal importance for university (marked in grey colour). It can be seen that the first group is more important. As a result, it can be concluded that the most important principles for students are those associated with relations between the university and general environment, followed by those focused on education, while those regarding relations with specific stakeholders and especially internal university actions are less important.

The result of the Chi-squared test shows that there is a statistically significant association between the perception of the importance of the University Social Responsibility objectives and specific students' characteristics (bolded in Table 5). 
Table 5. Chi-squared test results for the perception of the importance of the University Social Responsibility objectives.

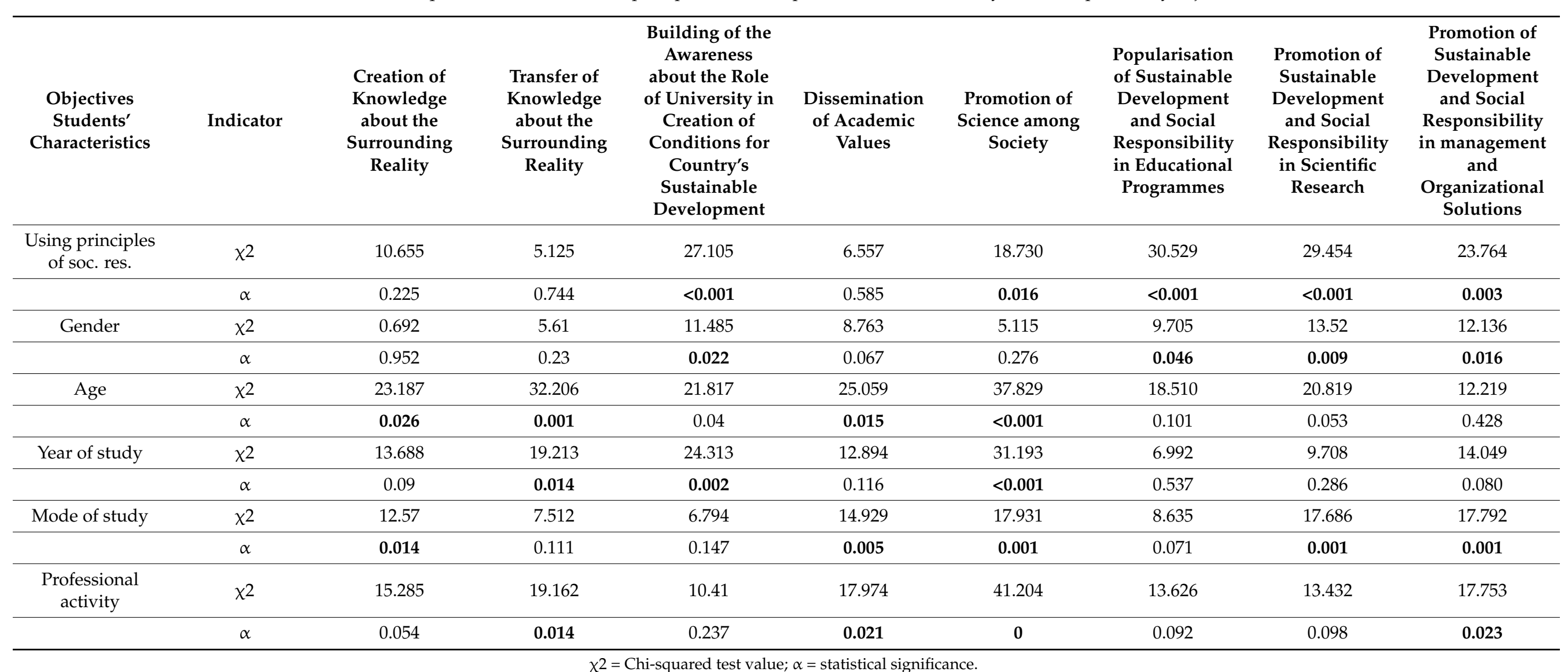


The strongest relation is in two cases-the declared extent to which respondents observe the principles of social responsibility in their everyday life and mode of study. In five of the eight variables, statistically significant associations can be noticed in both cases. In most of the cases, the more students use principles of social responsibility in their everyday life, the higher they rate the extent to which universities should pursue the objectives of University Social Responsibility. Taking into account mode of study, full-time students rated the importance of specific objectives higher than part-time ones. The only exception was popularization of science among society, which was rated higher by part-time students.

The second important group of students' characteristics includes their age, gender, and professional activity. In those cases, we can observe statistically significant associations between the above-mentioned variables and the importance of four objectives of University Social Responsibility. In the case of age, we can observe the highest rating of importance for such objectives as creation and transfer of knowledge about the surrounding reality, as well as building of awareness about the role of university in creation of conditions for country's sustainable development, among older groups of students. On the other hand, the objective related to the popularization of science among the society was rated the highest by the group of students of 21-22 years old and 27 years old and older. In the case of gender, the objectives were rated higher by women. In addition, students who work (regardless of form) rated some of the objectives higher.

The least important was the year of study. Usually, the highest ratings of USR's objectives were observed among master's degree and doctoral or postgraduate students.

Results of the Chi-squared test also show that there is a statistically significant association between students' characteristics and their personal importance ratings of specific principles of the University Social Responsibility Programme (bolded in Tables 6 and 7).

The most important characteristic is again the extent to which respondents declared they use the principles of social responsibility in their everyday life. Statistically significant associations are observed between this and 8 of 12 principles of USR. In all cases, the more students use principles of social responsibility in their everyday life, the higher they personally rate specific principles of the University Social Responsibility programme.

The second important group of characteristics of students consisted of their year of study, mode of study and professional activity. Statistically significant association is observed for each characteristic with five principles. In the first case, the highest ratings are observed within the group of doctoral and postgraduate students and among master's degree students. Full-time students rated the importance of specific principles of the University Social Responsibility programme higher than part-time ones. The students active in the labour market also rated the importance of specific principles higher than those unemployed.

Statistically significant association between age and personal importance rating of specific principles of the USR programme can be observed in only four cases. Generally, among older groups of students, we can observe higher ratings of specific principles. There is only one exception. In the case of the activity of the academic community and their stakeholders in a way that minimizes its negative impact on the natural environment, the highest ratings were among the youngest and the oldest respondents. Gender does not have any statistically significant impact on this rating. 
Table 6. Chi-squared test results for personal importance rating of specific principles of the University Social Responsibility programme (part A).

\begin{tabular}{|c|c|c|c|c|c|c|}
\hline \multirow[t]{2}{*}{ Students' Characteristics Specific Principles } & \multicolumn{2}{|c|}{ Using Principles of Social Responsibility } & \multicolumn{2}{|c|}{ Gender } & \multicolumn{2}{|c|}{ Age } \\
\hline & $x^{2}$ & $\alpha$ & $\chi^{2}$ & $\alpha$ & $x^{2}$ & $\alpha$ \\
\hline $\begin{array}{l}\text { Dissemination of ideas of equal opportunities, diversity, } \\
\text { tolerance and respect for human rights }\end{array}$ & 19.036 & 0.015 & 3.376 & 0.497 & 8.446 & 0.749 \\
\hline $\begin{array}{l}\text { Activity of academic community and their stakeholders in a way that minimizes its } \\
\text { negative impact on natural environment }\end{array}$ & 31.757 & $<0.001$ & 3.072 & 0.546 & 21.363 & 0.045 \\
\hline Providing transparency of university's activity & 9.640 & 0.291 & 1.36 & 0.851 & 21.784 & 0.040 \\
\hline $\begin{array}{c}\text { Development of national and international intercollegiate cooperation in terms of } \\
\text { exchange of social responsibility models }\end{array}$ & 24.610 & 0.002 & 8.98 & 0.062 & 23.298 & 0.025 \\
\hline $\begin{array}{c}\text { Dialogue with stakeholders about priorities of USR policy and providing } \\
\text { information about its results }\end{array}$ & 23.679 & 0.003 & 1.87 & 0.76 & 13.075 & 0.364 \\
\hline Creation of social and civic attitudes of future elites towards building work ethics & 8.953 & 0.346 & 2.231 & 0.693 & 12.614 & 0.398 \\
\hline $\begin{array}{l}\text { Extension of educational programmes of issues related to ethics and corporate social } \\
\text { responsibility, sustainable development and social innovations }\end{array}$ & 17.497 & 0.025 & 1.624 & 0.804 & 13.584 & 0.328 \\
\hline Submitting the rules of ethics and responsibility in education and research processes & 26.503 & $<0.001$ & 1.986 & 0.738 & 18.156 & 0.111 \\
\hline $\begin{array}{l}\text { Taking care of academic values (e.g., those mentioned in the } \\
\text { "Code of Ethics of a Researcher") }\end{array}$ & 3.027 & 0.933 & 4.754 & 0.313 & 22.754 & 0.030 \\
\hline $\begin{array}{c}\text { Undertaking projects implementing the principles of social responsibility in the } \\
\text { process of University management }\end{array}$ & 30.288 & $<0.001$ & 5.871 & 0.209 & 9.730 & 0.604 \\
\hline $\begin{array}{c}\text { Taking care of university's organizational order in strategies and } \\
\text { actions based on principles of USR }\end{array}$ & 22.077 & 0.005 & 7.018 & 0.135 & 20.235 & 0.063 \\
\hline
\end{tabular}


Table 7. Chi-squared test results for personal importance rating of specific principles of the University Social Responsibility programme (part B).

\begin{tabular}{|c|c|c|c|c|c|c|}
\hline \multirow[t]{2}{*}{ Student's Characteristics Specific Principles } & \multicolumn{2}{|c|}{ Year of Study } & \multicolumn{2}{|c|}{ Mode of Study } & \multicolumn{2}{|c|}{ Professional Activity } \\
\hline & $x^{2}$ & $\alpha$ & $x^{2}$ & $\alpha$ & $x^{2}$ & $\alpha$ \\
\hline $\begin{array}{l}\text { Dissemination of ideas of equal opportunities, diversity, } \\
\text { tolerance and respect for human rights }\end{array}$ & 5.364 & 0.718 & 7.402 & 0.116 & 4.351 & 0.824 \\
\hline $\begin{array}{l}\text { Activity of academic community and their stakeholders in a way that minimizes } \\
\text { its negative impact on natural environment }\end{array}$ & 11.654 & 0.167 & 9.229 & 0.56 & 12.473 & 0.131 \\
\hline Providing transparency of university's activity & 25.947 & 0.001 & 6.417 & 0.17 & 42.293 & 0 \\
\hline $\begin{array}{c}\text { Development of national and international intercollegiate cooperation in terms of } \\
\text { exchange of social responsibility models }\end{array}$ & 20.772 & 0.008 & 10.361 & 0.035 & 16.143 & 0.4 \\
\hline $\begin{array}{c}\text { Dialogue with stakeholders about priorities of USR policy and providing } \\
\text { information about its results }\end{array}$ & 10.871 & 0.209 & 4.734 & 0.316 & 20.23 & 0.01 \\
\hline Creation of social and civic attitudes of elites towards building work ethics & 13.786 & 0.088 & 4.625 & 0.328 & 9.181 & 0.327 \\
\hline $\begin{array}{l}\text { Extension of education programmes of issues related to ethics and CSR, sustainable } \\
\text { development and social innovations }\end{array}$ & 24.885 & 0.002 & 2.26 & 0.688 & 14.01 & 0.081 \\
\hline Submitting the rules of ethics and responsibility in education and research processes & 10.094 & 0.259 & 6.026 & 0.197 & 13.155 & 0.107 \\
\hline $\begin{array}{l}\text { Taking care of academic values (e.g., those mentioned in the } \\
\text { "Code of Ethics of a Researcher") }\end{array}$ & 25.446 & 0.001 & 12.657 & 0.013 & 11.407 & 0.18 \\
\hline $\begin{array}{l}\text { Undertaking projects implementing principles of social responsibility in the process } \\
\text { of University management }\end{array}$ & 9.172 & 0.328 & 10.563 & 0.032 & 13.105 & 0.108 \\
\hline $\begin{array}{c}\text { Taking care of university's organizational order in strategies and } \\
\text { actions based on principles of USR }\end{array}$ & 37.402 & $<0.001$ & 10.025 & 0.04 & 22.227 & 0.005 \\
\hline
\end{tabular}




\section{Discussion}

As can be seen, the University Social Responsibility Declaration is little known among students at the University of Economics in Katowice. Only about $20 \%$ of respondents declared that they had heard about the USRD. The problem may be the name of this document, because as different research shows, the concept of Corporate Social Responsibility is often given the same name when applied to higher education and is known by more than half of students [53]. It could be concluded that more intense promotion of the USRD is needed. Lower awareness of the USRD does not mean marginalization of perception of the USRD principles.

The results of the research show that the most important things for students linked with University Social Responsibility programmes are related to external relations of the university to the general environment. Those actions include, among others, the dissemination of the ideas of equal opportunities, diversity, tolerance and respect for human rights. The second most important group of principles was related to education processes. It is surprising that the two highest-rated groups of values for universities which sign this declaration were ordered in this way (lower meaning being given to education activities). Lower scores were obtained by groups of principles related to cooperation of the university with different stakeholders and actions focused on the internal environment implemented by the university. There is a coincidence between these results and results of the research presented by Vazquez et al. [51], who analysed perceptions and attitudes of students at one Uruguayan university towards Corporate Social Responsibility. Just as in the case of CSR, the most important principles of USR were related to general external relations of social responsibility for the institutional entity. This could mean that some cultural or geographical determinants do not have such a strong impact on perception of some USR principles as age or year of study of students, as was identified in this paper. In both cases, the second most important group was related to personal aimseducation in the case of USR and development of professional skills and work relations in the case of CSR. The least important group was related to the entity's relations with specific stakeholders. Similar results were obtained by Bourgoin and Vlachopoulos [62] in one European university. Respondents declared that the most important aspects of CSR at universities are protection of environment and social responsibility.

The results of the presented research show that the rating of most of the principles is related to general use of social responsibility principles in everyday life by students. It could be observed that full-time students rate importance of specific objectives higher than part-time ones. In addition, the students who are active in the labour market rate that importance higher than those unemployed. We observed the highest ratings within the group of doctoral and postgraduate students, followed by master's degree students, and ratings were generally higher among older students than younger ones. Gender does not have such a strong impact on ratings. This could provide advice for universities and their promotional campaigns targeted at candidates for master's, postgraduate, or doctoral studies. Universities should underline their activities related to USR in promotional actions.

Universities should more actively implement a social responsibility strategy (just like enterprises). The implementation of this strategy by the university creates an opportunity to evolve towards an organization serving the environment. It is more and more important to meet the expectations of the stakeholders (e.g., undergraduates, employers of alumni, media, and society) as well as inner stakeholders (departments, managers, and personnel). The identification of the expectations of university stakeholders (especially students as key stakeholders) is the starting point for such action.

Thanks to performed studies, it has been established that surveyed students, as a specific group of university stakeholders, do not have any knowledge about the USR Declaration. In their opinions, universities should emphasize transferring knowledge about the surrounding reality and popularizing science in society. The promotion of sustainable development and social responsibility in management and organizational solutions is also very important. These results show the importance of a university's 
communication policy (similar conclusions were reached by Pabian [52]), especially in the face of low declaration of awareness. The dissemination of ideas of equal opportunities, diversity, tolerance, and respect for human rights and activity that minimizes negative impact on the natural environment are the most important for the respondents.

There are a few limitations of the conducted research. Firstly, the research was focused on students representing one university. This university is a business school, and this could have an impact on the perception of University Social Responsibility. Other results could be obtained from students at universities of different education profiles. Whether the study program of the respondents was focused on issues of responsibility or sustainability, either in terms of the profile of the graduate or according to the completed subjects/courses, was not considered. These circumstances have an impact on the attitudes and knowledge of the respondents. Secondly, only one group of stakeholders were examined. Thirdly, the research focused on one country where USR is a new concept implemented in the last years.

The authors see a few directions for future research. There is a possibility to perform the same study among students at different universities in Poland and other countries. This could allow comparable analysis between different studies, including the analysis of the study program. In addition, different groups of stakeholders could be examined. The future research should include the design and development of a qualitative study focused on knowing why some of its results have taken place. In addition, the complexity of the relationship between the characteristics of students and the perception of USR requires deepening of research in the future.

Supplementary Materials: The following are available online at https:/ / www.mdpi.com/article/10 $.3390 /$ su13169417/s1, Questionnaire S1.

Author Contributions: Conceptualization, M.K., P.P., and J.W.; methodology, M.K., P.P., and J.W.; software, P.P.; validation, M.K., P.P., and J.W.; formal analysis, M.K., P.P., and J.W.; investigation, M.K., P.P., and J.W.; resources, P.P.; data curation, P.P.; writing — original draft preparation, M.K., P.P., and J.W.; writing—review and editing, M.K., P.P., and J.W.; visualization, M.K., P.P., and J.W.; supervision, M.K., P.P., and J.W. All authors have read and agreed to the published version of the manuscript.

Funding: This research received no external funding.

Institutional Review Board Statement: Not applicable.

Informed Consent Statement: Informed consent was obtained from all subjects involved in the study.

Data Availability Statement: Not applicable.

Conflicts of Interest: The authors declare no conflict of interest.

\section{References}

1. Vallaeys, F. Defining Social Responsibility: A Matter of Philosophical Urgency for University. Global University Network for Innovation. 2013. Available online: http://www.guninetwork.org/resources/he-articles/definingsocial-responsibility-a-matterof-urgency-for-philosophy-and-uniersities (accessed on 10 April 2021).

2. Szelagowska-Rudzka, K.I. University Social Responsibility—Good Practices of Polish Higher Education Institutions. Univ. Manag. Pr. Anal. 2019, 23, 43-52. [CrossRef]

3. Domínguez, M.J.; López, E. Estudiantes Universitarios Opinan Sobre la Responsabilidad Social Universitaria. Available online: https://buleria.unileon.es/bitstream/handle/10612/1506/Hum8_art9.pdf?sequence=1 (accessed on 10 April 2021).

4. Arango Tobón, O.; Clavijo Zapata, S.; Puerta-Lopera, I.; Sánchez-Duque, J.W. Formación académica, valores, empatía y comportamientos responsables en estudiantes universitarios. Rev. Educ. Super. 2014, 43, 89-105.

5. Vázquez, J.L.; Aza, C.L.; Lanero, A. Are students aware of university social responsibility? Some insights from a survey in a Spanish university. Int. Rev. Public Nonprofit Mark. 2014, 11, 195-208. [CrossRef]

6. González-Rodríguez, R.; Díaz-Fernández, C.; Biagio, S. Values and corporate social initiative?: An approach through Schwartz theory. Int. J. Bus. Soc. 2014, 15, 19-48.

7. Dahlsrud, A. How corporate social responsibility is defined: An analysis of 37 definitions. Corp. Soc. Responsib. Environ. Manag. 2008, 15, 1-13. [CrossRef]

8. Freeman, I.; Hasnaoui, A. The Meaning of Corporate Social Responsibility: The Vision of Four Nations. J. Bus. Ethics 2010, 100, 419-443. [CrossRef] 
9. Harris, M.J. Basic principles of Sustainable Development. In Dimensions of Sustainable Development; Bawa, K.S., Seidler, R., Eds.; EOLSS Publishers: Oxford, UK, 2009; Volume I, pp. 21-40.

10. Morreale, A.; Mittone, L.; Vu, T.-T.-T.; Collan, M. To Wait or Not to Wait? Use of the Flexibility to Postpone Investment Decisions in Theory and in Practice. Sustainability 2020, 12, 3451. [CrossRef]

11. Dabija, D.C. Sustainable Business Marketing. Amfiteatru Econ. 2015, 17, 851-853.

12. Davis, K.; Blomstrom, R. Business and Society: Environment and Responsibility; McGraw-Hill Inc.: New York, NY, USA, 1975.

13. Carroll, A.B. The Four Faces of Corporate Citizenship. Bus. Soc. Rev. 1998, 100-101, 1-7. [CrossRef]

14. Lyon, D. How can you help organizations change to meet the corporate responsibility agenda? Corp. Soc. Responsib. Environ. Manag. 2004, 11, 133-139. [CrossRef]

15. Oskarsson, K.; Von Malmborg, F. Integrated management systems as a corporate response to sustainable development. Corp. Soc. Responsib. Environ. Manag. 2005, 12, 121-128. [CrossRef]

16. Stefańska, M.; Śmigielska, G. CSR as a source of competitiveness of distribution channels. Zesz. Nauk. Szkoty Głównej Gospod. Wiej. Warszawie Polityki Eur. Finans. Mark. 2013, 9, 491-502.

17. Dabija, D.-C.; Postelnicu, C.; Dinu, V. Cross-Generational Investigation of Ethics and Sustainability. Insights from Romanian Retailing. In Global Challenges to CSR and Sustainable Development; Springer Science and Business Media LLC: Berlin/Heidelberg, Germany, 2018; pp. 141-163.

18. Kieżel, M. Manifestations of implementation of the CSR concept in the retail banking sector in Poland. Eur. J. Serv. Manag. 2018, 25, 117-124. [CrossRef]

19. Ebner, D.; Baumgartner, R.J. The Relationship between Sustainable Development and Corporate Social Responsibility. In Proceedings of the Corporate Responsibility Research Conference 2006, Dublin, Ireland, 4-5 September 2016. Available online: http:/ / www.crrconference.org/Previous_conferences/downloads/2006ebnerbaumgartner.pdf (accessed on 15 March 2021).

20. Grzegorzewska-Ramocka, E. Development of the Corporate Social Responsibility Concept. Gospod. Nar. 2004, 195, 65-85. [CrossRef]

21. Van Der Woerd, F.; Brink, T.V.D. Feasibility of a Responsive Business Scorecard? A pilot study. J. Bus. Ethics 2004, 55, 173-186. [CrossRef]

22. Salzmann, O.; Steger, U. Die Soziale Verantwortung von Unternehmen; Harvard Businessmanager: Hamburg, Germany, 2006 Available online: https:/ / heft.manager-magazin.de/EpubDelivery/manager-lounge/pdf/47328785 (accessed on 15 March 2021).

23. Laszlo, C. Firma Zrównoważonego Rozwoju; Studio Emka: Warszawa, Poland, 2008; p. 34.

24. Wild, J.J.; Wild, K.L.; Han, J.C.Y. International Business. The Challenges of Globalization; Pearson Education Inc.: Upper Saddle River, NJ, USA, 2003.

25. Jeżowski, P. Rozwój zrównoważony we współczesnych koncepcjach ekonomicznych. In Zrównoważony Rozwój; Poskrobko, B., Kozłowski, S., Eds.; PAN Komitet „Człowiek i Środowisko”: Warszawa, Poland, 2005.

26. European Commission. Promoting a European Framework for Corporate Social Responsibility; Office for Official Publications of the European Communities: Luxembourg, 2001; p. 20.

27. Commission of European Communities. CSR and SMEs. Commission CSR Policy. 2007. Available online: http://ec.europa.eu/ enterprise/csr (accessed on 15 March 2021).

28. Wood, D.J. Corporate Social Performance Revisited. Acad. Manag. Rev. 1993, 16, 691-718. [CrossRef]

29. Clarkson, M.B.E. A Stakeholder Framework for Analyzing and Evaluating Corporate Social Performance. Acad. Manag. Rev. 1995, 20, 92-117. [CrossRef]

30. Carroll, A.B. Corporate Social Responsibility: Evolution of a Definitional Construct. Bus. Soc. 1999, 38, 268-295. [CrossRef]

31. Hohnen, P. Corporate Social Responsibility: An Implementation Guide for Business; International Institute for Sustainable Development: Winnipeg, MB, Canada, 2007.

32. UNESCO. A Human Right-Based Approach to Education. 2007. Available online: http:/ /www.unicef.org/purblications / files/ A_Human_Rights_Based_Approach_to_Education_for_All.pdf (accessed on 19 February 2021).

33. Shek, D.T.L.; Yuen-Tsang, A.W.K.; Ng, E.C.W. USR Network: A Platform to Promote University Social Responsibility. In University Social Responsibility and Quality of Life: A Global Survey of Concepts and Experiences; Shek, D.T.L., Hollister, R.M., Eds.; Springer: Berlin/Heidelberg, Germany, 2017.

34. Giuffre, L.; Ratto, S.E. A New Paradigm in Higher Education: University Social Responsibility. J. Educ. Hum. Dev. 2014, 3, 231-238.

35. Reiser, J. Managing University Social Responsibility (USR). 2008. Available online: http://www.international-sustainablecampus-network.org/iscn-conference-2007/view-category.html (accessed on 19 February 2021).

36. Domínguez Pachón, M.J. Responsabilidad Social Universitaria. Humanismo Trab. Soc. 2009, 8, 37-67.

37. Vasilescu, R.; Barna, C.; Epure, M.; Baicu, C. Developing university social responsibility: A model for the challenges of the new civil society. Procedia Soc. Behav. Sci. 2010, 2, 4177-4182. [CrossRef]

38. Esfijani, A.; Hussain, F.; Chang, E. University social responsibility ontology. Eng. Intell. Syst. 2013, 4, $271-281$.

39. González-Alcántara, O.J.; Fontaneda González, I.; Camino López, M.A.; Antón Lara, A. La Responsabilidad Social en las Universidades Españolas 2010; iGR—Grupo de Investigación Ingenieria y Gestión Responsible: Burgos, Spain; Universidad de Burgos: Burgos, Spain, 2010. Available online: https://goo.gl/fYgwZN (accessed on 19 February 2021).

40. Tetřevová, L.; Sabolová, V. University Stakeholder Management and University Social Responsibility. WSEAS Trans. Adv. Eng. Educ. 2010, 7, 229-230. 
41. Dima, A.M.; Vasilache, S.; Ghinea, V.; Agoston, S. A model of academic social responsibility. Rev. Adm. Sci. 2013, 9, $23-43$.

42. Brdulak, A. Social Responsibility at Polish Universities: Based on the Example of WSB University in Wroclaw. In CSR in Contemporary Poland; Bachnik, M., Kaźmierczak, M., Rojek-Nowosielska, M., Stefańska, M., Szumniak-Samolej, J., Eds.; Springer Science and Business Media LLC: Berlin/Heidelberg, Germany, 2020; pp. 71-83.

43. Chen, S.-H.; Nasongkhla, J.; Donaldson, J.A. University Social Responsibility (USR): Identifying an Ethical Foundation within Higher Education Institutions. TOJET Turk. Online J. Educ. Technol. 2015, 14, 166.

44. Buchholz, R.A.; Rosenthal, S.B. Toward a Contemporary Conceptual Framework for Stakeholder Theory. J. Bus. Ethics 2005, 58, 137-148. [CrossRef]

45. Grassa, V.M.; Lloret, J.; Rodríguez, C.; Romero, L.; Sanabria, E.; Sanchis, V. Cooperative Work for Teacher Training. WSEAS Trans. Adv. Eng. Educ. 2008, 5, 69-76.

46. Moubayed, N.; Bernard, M.; Jammal, A. A Survey of Engineering Education in Developing Countries: The Lebanese Case. WSEAS Trans. Adv. Eng. Educ. 2009, 6, 430-441.

47. Sánchez-Hernández, M.I.; Mainardes, E.W. University social responsibility: A student base analysis in Brazil. Int. Rev. Public Nonprofit Mark. 2016, 13, 151-169. [CrossRef]

48. Moon, J.; Herzig, C.; Godemann, J.; Bebbington, J. Special Issue on Social Accountability and Stakeholder Engagement for Sustainability: Shaping Organisational Change in Higher Education? 1st ed.; Accounting, Auditing and Accountability Journal Series; Emerald Group Publishing: London, UK, 2012.

49. González-Rodríguez, M.R.; Díaz-Fernández, M.C.; Pawlak, M.; Simonetti, B. Perceptions of students university of corporate social responsibility. Qual. Quant. 2012, 47, 2361-2377. [CrossRef]

50. Martínez-Usarralde, M.-J.; Lloret-Catalá, C.; Mas-Gil, S. Responsabilidad Social Universitaria (RSU): Principios para una universidad sostenible, cooperativa y democrática desde el diagnóstico participativo de su alumnado. Educ. Policy Anal. Arch. 2017, 25, 75. [CrossRef]

51. Vázquez, J.L.; Lanero, A.; Licandro, O. Corporate Social Responsibility and Higher Education: Uruguay University Students' Perceptions. Econ. Sociol. 2013, 6, 145-157. [CrossRef]

52. Pabian, A. University Social Responsibility in the opinion of students. Forum Sci. Oecon. 2019, 7, 101-117.

53. Gómez, L.M.; Naveira, Y.A.; Bernabel, A.P. Implementing University Social Responsibility in the Caribbean: Perspectives of Internal Stakeholders. Rev. Digit. Investig. Docencia Univ. 2018, 12, 101-120. [CrossRef]

54. Wang, L.; Juslin, H. Values and Corporate Social Responsibility Perceptions of Chinese University Students. J. Acad. Ethics 2012, 10, 57-82. [CrossRef]

55. Elias, R.Z. An Examination of Business Students' Perception of Corporate Social Responsibilities Before and After Bankruptcies. J. Bus. Ethics 2004, 52, 267-281. [CrossRef]

56. Chatzopoulou, E.; de Kiewiet, A. Millennials' evaluation of corporate social responsibility: The wants and needs of the largest and most ethical generation. J. Consum. Behav. 2021, 20, 521-534. [CrossRef]

57. Science in Poland. 58 Universities have Signed the University Social Responsibility Declaration. Available online: http: / / naukawpolsce.pap.pl/aktualnosci/news\%2C78627\%2C58-uczelni-podpisalo-deklaracje-spolecznej-odpowiedzialnosciuczelni.htm (accessed on 15 March 2021).

58. USR Network Homepage. Available online: http:/ / www.usrnetwork.org/about-usrn/background (accessed on 18 July 2021).

59. EU-USR. University Social Responsibility: A Common European Reference Framework. Available online: http://www.eu-usr. eu/wp-content/uploads/2015/04/D1.4-Final-Report-Public-Part-EN.pdf (accessed on 18 July 2021).

60. Center for University Social Responsibility Ministry of Education, Taiwan. Available online: https://www.2020usrexpo.org/en/ USR.php (accessed on 18 July 2021).

61. Vallaeys, F.; De La Cruz, C.; Sasia, P.M. Responsabilidad Social Universitaria, Manual de Primeros Pasos; McGrawHill: Mexico City, Mexico, 2009.

62. Bourgoin, P.; Vlachopoulos, D. Complementary perspectives in the study of teaching conceptions. In Proceedings of the EDULEARN19 Proceedings 11th International Conference on Education and New Learning Technologies, Palma, Spain, 1-3 July 2019; pp. 1756-1763. 